\title{
Amplitude variation with offset (AVO) analysis via fluid replacement modeling (FRM) for characterizing the reservoir response of Cretaceous sand interval
}

\author{
Analiza zmiany amplitudy z offsetem (AVO) w poziomie złożowym piaskowców \\ kredowych w celu określenia odpowiedzi sejsmicznej na modelowanie zastępowania \\ medium nasycającego (FRM)
}

\author{
Muhammad Rizwan Mughal $^{1,2}$, Gulraiz Akhter ${ }^{1}$ \\ ${ }^{1}$ Department of Earth Sciences, Quaid-i-Azam University, Islamabad, Pakistan \\ ${ }^{2}$ Department of Meteorology, COMSATS University Islamabad, Pakistan
}

\begin{abstract}
The reservoir pore fluid at various saturation levels can be modeled and analyzed through fluid replacement modeling (FRM) by applying Gassmann's theory. The FRM technique was applied to a gas-prone reservoir (Cretaceous C-sand interval) of the Lower Goru Formation in the Sawan gas field, Middle Indus Basin, Pakistan. 3D post-stack seismic data and wireline log data of two exploration wells (Sawan-01 and Sawan-08) were utilized in the study. The petrophysical analysis of wells was carried out to initially predict the gas-bearing zones of the reservoir interval at well locations, and later on to predict areas away from the well through seismic to well tie. The amplitude variation with offset (AVO) behavior was analyzed by replacing the in situ fluid saturation level with a modeled $80 \%$ gas and $20 \%$ water saturation in the reservoir. The elastic properties of the reservoir sand were estimated through rock physics based on Gassmann equations. The AVO response under both in situ and FRM conditions indicated that the reservoir gas sand exhibits a typical class IV signature. The increase of reflection amplitude with angle in FRM synthetic gathers showed AVO sensitivity to changes in fluid type and saturation. The change in reservoir parameters with a change in fluid saturation levels and their AVO response was well-captured in the analysis for effective identification of lithology and fluid concentration in the reservoir. Moreover, the methodology followed in this study will be helpful for better characterizing hydrocarbon-bearing reservoirs within the study region and in various other parts of the world.
\end{abstract}

Key words: Fluid replacement modeling (FRM), elastic parameters, AVO response, gas saturation effect, Sawan gas field.

STRESZCZENIE: Wykorzystanie teorii Gassmana w modelowaniu zastępowania medium nasycającego (fluid replacement modeling - FRM) przestrzeń porową pozwala na stworzenie syntetycznych modeli ośrodka geologicznego o różnym stopniu nasycenia. Metodyka FRM została wykorzystana w skałach zbiornikowych złoża gazu ziemnego Sawan (środkowy basen Indusu, Pakistan) zlokalizowanego w poziomie piaszczystym C kredowej formacji Lower Goru. W badaniach wykorzystano sejsmikę w wersji post-stack oraz dane otworowe (Sawan-01 oraz Sawan-08). Analizę petrofizyczną danych otworowych przeprowadzono w celu wstępnego prognozowania stref nasyconych gazem w lokalizacjach odwiertów, a następnie poprzez dowiązanie danych sejsmicznych do otworowych przeprowadzono predykcję nasycenia dla całego wolumenu sejsmicznego 3D. Analiza zmian amplitudy z offsetem (AVO) w obrębie interwału perspektywicznego prowadzona była dla aktualnego poziomu nasycenia skał zbiornikowych in situ oraz dla modelowanego przypadku zmiany parametrów nasycenia (nasycenie gazem $80 \%$, nasycenie wodą złożową 20\%). Parametry elastyczne złoża zostały oszacowane na podstawie wzorów Gassmanna. Odpowiedź AVO dla danych in situ oraz dla danych syntetycznych FRM wskazuje na IV klasę AVO. Obserwowany wzrost amplitudy w funkcji kąta padania dla modeli FRM wykazuje czułość metody AVO na zmianę medium nasycającego przestrzeń porową. Zmiana parametrów złoża związana ze zmianą stopnia nasycenia medium i obserwowaną zmianą w odpowiedzi AVO potwierdza efektywność zastosowanej metody w określaniu litologii i nasycenia skały złożowej. Wykorzystana metodologia pozwoli na dokładniejszą charakterystykę formacji złożowych zarówno w obszarze badań, jak również w innych rejonach świata.

Słowa kluczowe: modelowanie zastępowania medium nasycającego (FRM), parametry sprężyste, odpowiedź AVO, efekt nasycenia gazem, złoże gazu Sawan.

Corresponding author: M.R. Mughal, e-mail:mmrizwan@student.qau.edu.pk

Article contributed to the Editor: 20.01.2020. Approved for publication: 14.05.2020 


\section{Introduction}

Fluid replacement modeling (FRM) is a valuable tool for modeling and analyzing the seismic responses to various fluid scenarios (Smith et al., 2003). The technique has had a significant impact on seismic attribute studies because it allows the interpreter to generate seismic responses for reservoirs under varying fluid conditions (Singleton and Kierstead, 2009; Yuping et al., 2010; Rizwan et al., 2018). In FRM, the pore fluids are replaced from a known saturation to a new saturation level, and new acoustic parameters are theoretically calculated. Rock physics should be incorporated for a better understanding of how the elastic properties (compressional $(V p)$ and shear $(V s)$ velocities, density, impedance, and velocity ratio $[V p / V s]$ ) vary with FRM (Mavko et al., 2009; Grana et al., 2012).

One of the reliable indicators of hydrocarbon expression in seismic data is the AVO technique. The AVO technique works under the concept of varying amplitude (increase or decrease) with offset, that can be related to reservoir pore fluid content and rock physical properties (Ostrander, 1984; Castagna and Swan, 1997; Batzle et al., 2001). The basis of AVO is the dependence of reflection on offset, based on the fact that the upper and lower parts of the interface, having different physical properties, affect the seismic amplitudes at the boundaries. The amplitude anomalies of various rock-fluid properties are a function of effective density $\left(\rho_{e f f}\right)$, incident angle of seismic waves, and $V p$ and $V s$ wave velocity (Mavko et al., 2009). Zoeppritz's equations (1919) are widely used to study the AVO response and to describe the relationships between reflected, transmitted, and refracted compressed and shear waves for both media. The coefficients of reflection and transmission in each radiation angle are fully determined by density and the $P$ and $S$ wave velocity in each media. These parameters are affected by the change in the physical properties of the media. Due to the complex form of the Zoeppritz equations and a lack of intuitive understanding of how amplitudes are related to the various physical parameters, a number of linearized approximations have been made by geoscientists (Aki and Richards, 1980; Shuey, 1985; Fatti et al., 1994; Gray et al., 1999). The approximation published by Shuey (1985) showed a closed form of Zoeppritz equations and provided an advance insight into the work of Ostrander (1984). This involved $V p$, $\rho$, and Poisson's ratio (PR) rather than shear compressional velocity and the $V p / V s$ velocity ratio:

$R(\theta)=R_{o}+\left[R_{p} A_{o}+\frac{\Delta P R}{(1-P R)^{2}}\right] \sin ^{2} \theta+\frac{\Delta \alpha}{2 \alpha}\left(\tan ^{2} \theta-\sin ^{2} \theta\right)(1)$

where $R_{o}$ is the normal reflection coefficient of the P-wave and $P R, \triangle P R, A_{o}$, and $B$ are defined respectively as

$$
\begin{aligned}
& P R=\frac{P R_{1}+P R_{2}}{2} ; \Delta P R=P R_{1}-P R_{2} ; \\
& A_{o}=B-2(1+B) \frac{1-2 P R}{1-P R} ; B=\frac{\frac{\Delta P R}{P R}}{\frac{\Delta P R}{P R}+\frac{\Delta \rho}{\rho}}
\end{aligned}
$$

The above equation can be simplified by using various assumptions to

$$
R(\theta)=R_{o}+G_{A} \sin ^{2} \theta
$$

where $R_{o}$ is the normal incidence compressional wave coefficient and $G_{A}$ is the slope. For deriving various attributes and quantities, intercept $\left(R_{o}\right)$ and gradient $\left(G_{A}\right)$ are usually estimated through linear regression analysis on the seismic amplitudes at different offsets (Castagna and Smith, 1994).

The gas sand reflections are classified based on different AVO responses. Rutherford and Williams (1989) classified the AVO curve response into class I, class II, and class III. Class I has a high acoustic impedance (AI), class II has an AI value similar to shale, and class III has a lower AI than the overlying shales. Castagna et al. (1998) introduced a class IV AVO change for cases where the normal reflection coefficient is negative and becomes more positive as the offset increases (negative $R_{o}$ and positive $G_{A}$ ). The fluid substitution/replacement method is a widely used technique based on the application of Gassmann's equation (1951). In this method, AVO response is analyzed by changing the type of fluid in the reservoir zone using Shuey's equation (1985). The results of fluid replacement are the new seismic characteristics of the reservoir, including density, $V p$, and $V s$.

In the present study, we analyzed the response of elastic properties of the reservoir and AVO through FRM. In FRM we theoretically calculated new acoustic parameters (i.e., moduli, densities, and velocities) by changing the pore fluid from in situ/ initial saturation to a new saturation. The seismic response and AVO behavior of the reservoir in different conditions of pore fluid was estimated and compared with seismic parameters. Gassmann's equation (1951) is used to quantify the effect of fluid on the seismic properties of the reservoir and on AVO attributes under in situ conditions.

\section{Petroleum play of the study region}

The study area of the Sawan gas field (Fig. 1) lies in the Middle Indus Basin, between $24^{\circ} \mathrm{N}$ and $28^{\circ} \mathrm{N}$ latitude and from $66^{\circ} \mathrm{E}$ longitude, along the eastern border of Pakistan (Zaigham \& Mallick, 2000). The study area is bounded by several structural highs and lows within the tectonically controlled basement from the Precambrian age (Seeber et al., 1980). 


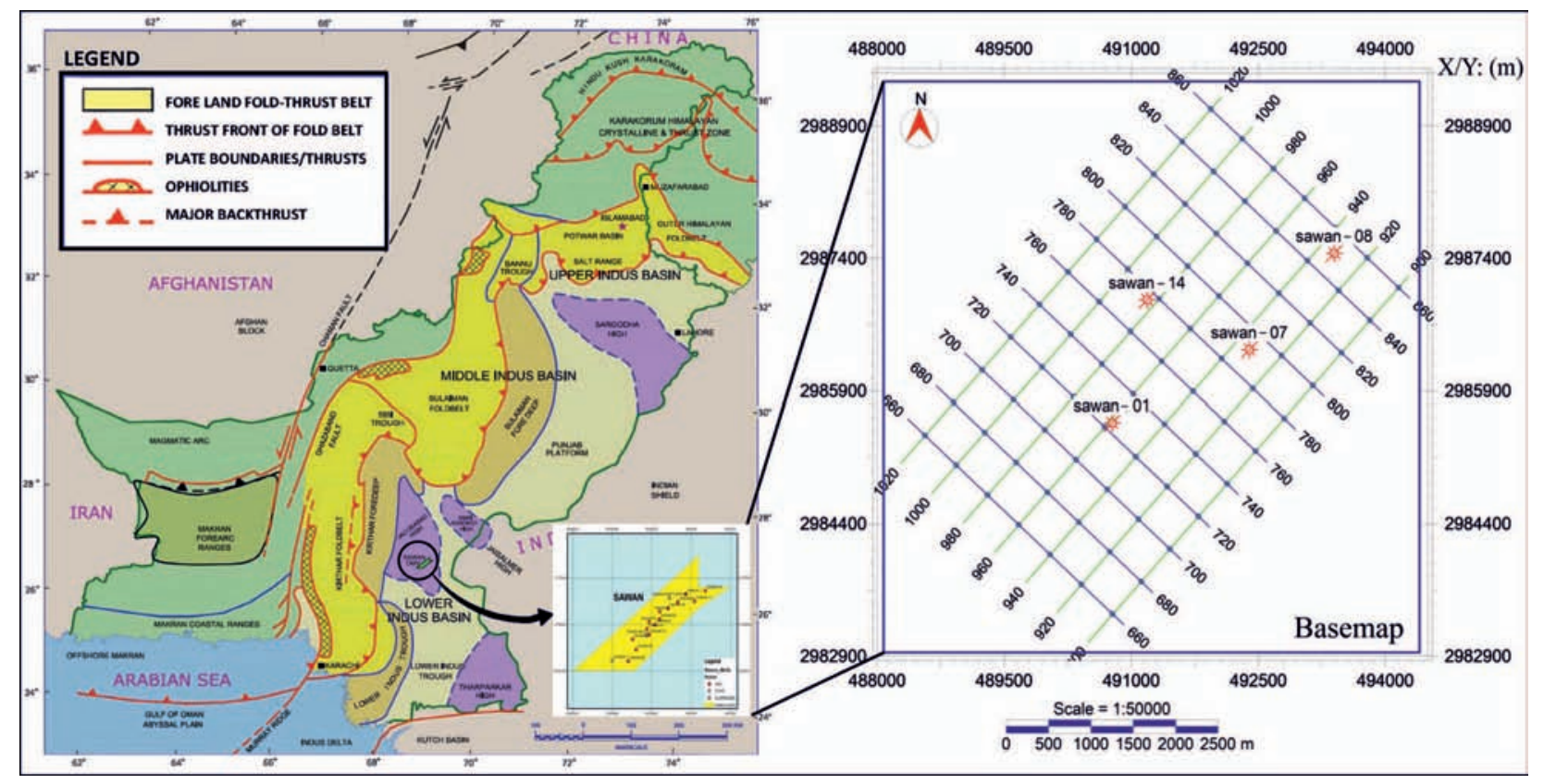

Fig. 1. Map showing the study area of the Sawan gas field, along with a basemap

Rys. 1. Mapa obszaru badań wraz ze złożem gazu ziemnego Sawan oraz szkicem lokalizacji odwiertów

The Jacobabad-Khairpur and Mari-Kandkot Highs cover the southern side of the study area and the Sargodha High covers the northern side (Fig. 1). The Indian Shield and Kirthar range bound the area from eastern and western sides, respectively (Afzal et al., 2009). The horst structure of the JacobabadKhairpur high divides the Indus Basin into the Central and Southern Basins, and the Sawan area is situated on the southeastern flank of this High.

The uplifting of the Jacobabad-Khairpur High significantly developed the structural traps of reservoir quality in the Sawan area and in other adjacent exploration fields during the Cretaceous period (Kazmi and Jan, 1997; Afzal et al., 2009). The stratigraphic sequence (Jurassic to Quaternary age), ranging from Chiltan limestones at the base to alluvial rocks at the top, covers the Sember and Lower Goru Formations in between from the Cretaceous period. The Sembar Formation is a proven source rock of the Indus Basin and is mainly comprised of black shale with minor filling of sandstone, argillaceous limestone, and dark siltstone (Quadri and Shuaib, 1986). The Lower Goru Member of the Goru Formation covers the Sembar Formation and is considered to be the major reservoir unit of the study area. The $\mathrm{C}$-sand interval of the Lower Goru Member covers the main gas reservoirs in the study area, accommodating a high porosity of around 16\% within the depth range of 3000-3500 m (Afzal et al., 2009). The Upper Goru Member consists of reservoir transgressive shales, siltstones, and marls, which acts as a regional seal in the study region (Berger et al., 2009).

\section{Dataset and methodology}

The log data from two exploration wells (Sawan-01 and Sawan-08) were used to analyze the sand and interbedded shale distribution within the $\mathrm{C}$-sand reservoir interval. The wireline logs, including sonic (DT), gamma ray (GR), density (Rho), resistivity, neutron porosity (NPHI), density porosity (POR), and 3D post-stack seismic data were used to analyze the effect of FRM on reservoir seismic properties and AVO response. The general workflow adopted for petrophysical analysis to quantify the reservoir parameters is presented in Fig. 2.

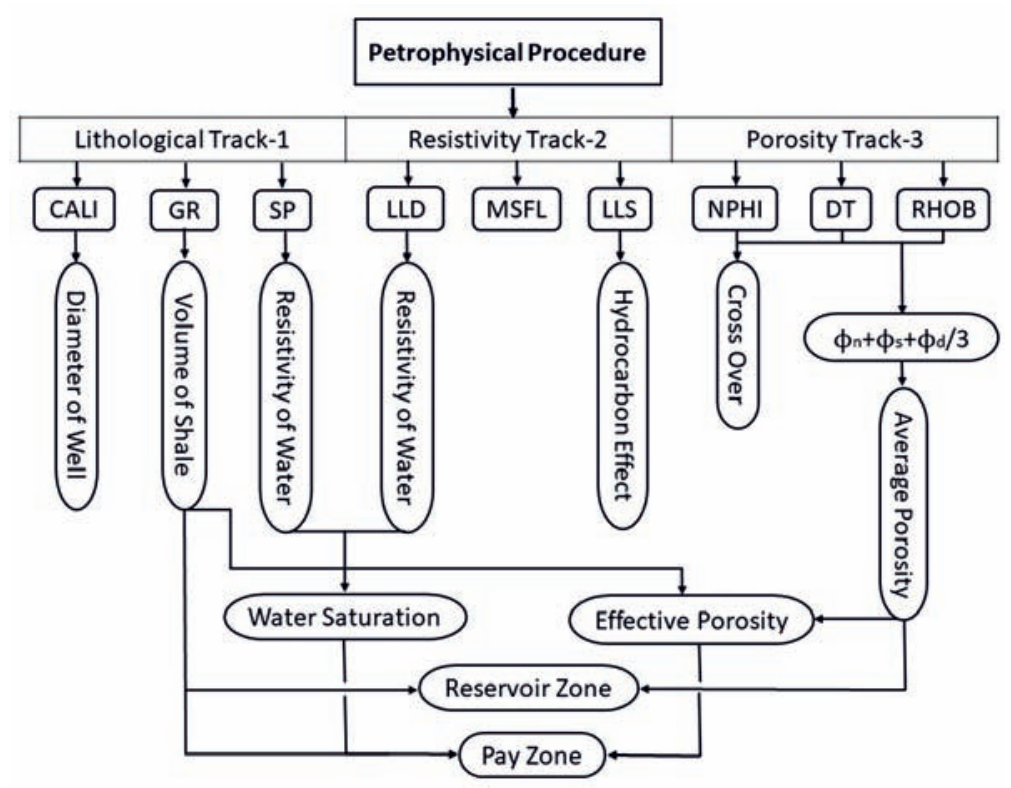

Fig. 2. The workflow adopted for petrophysical analysis in this study

Rys. 2. Procedura analizy petrofizycznej zastosowana w niniejszej pracy 


\section{NAFTA-GAZ}

The quantitative petrophysical analysis of wells (Sawan-01 and Sawan-08) was carried out to determine reservoir parameters such as a hydrocarbon-bearing zone, the volume of shale $\left(V_{s h}\right)$, average porosity $(\phi)$, density $(\rho)$, and average water saturation $\left(S_{w}\right)$ for the C-sand of the Lower Goru Formation (Figs. 3 and 4).

The estimated reservoir parameters of the C-sand interval are given in detail in Table 1.

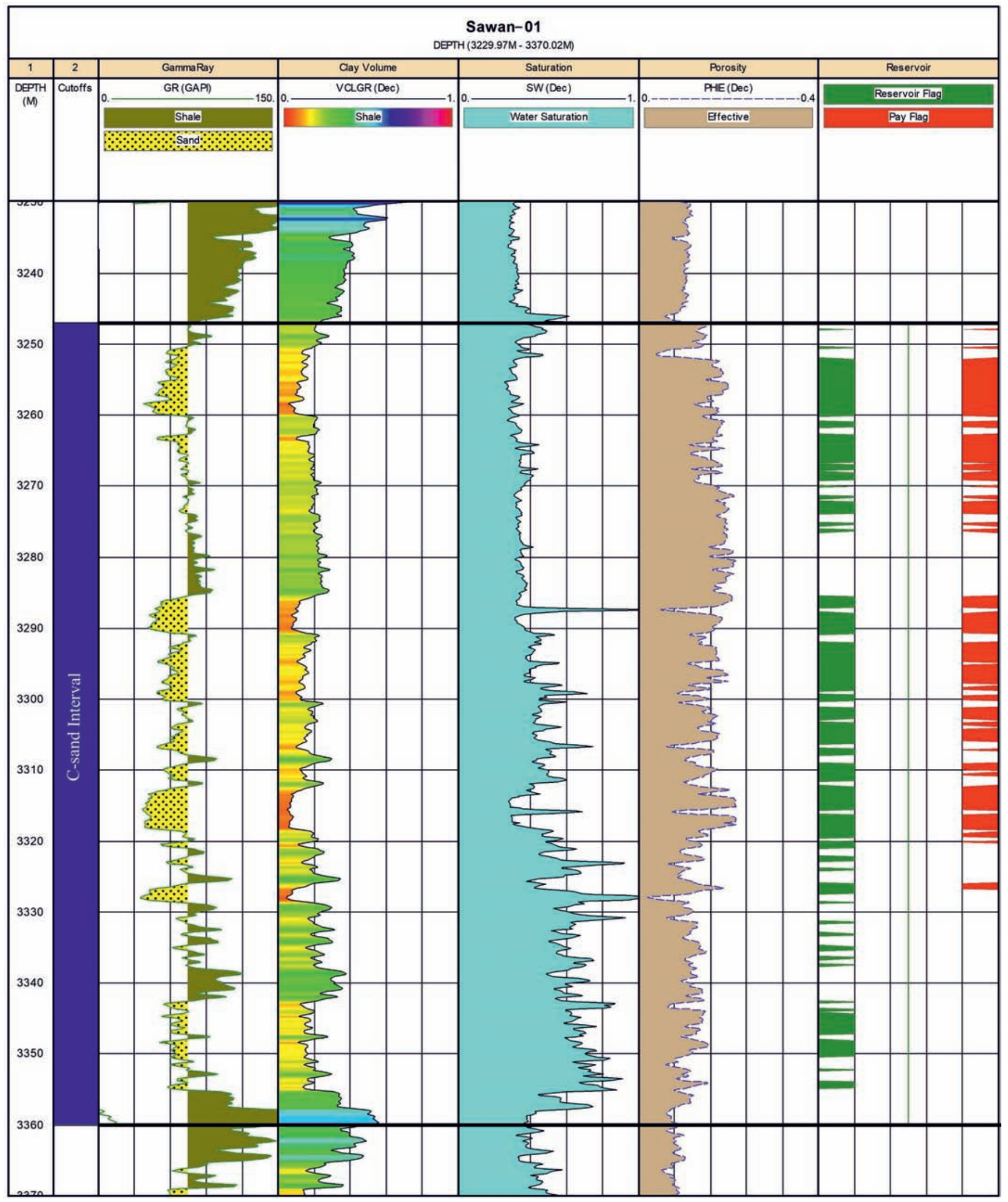

Fig. 3. Log curves and estimated petrophysical parameters within the reservoir C-sand interval of the well Sawan-01

Rys. 3. Profilowania i szacowane parametry petrofizyczne dla piaskowców poziomu złożowego C w otworze Sawan-01 


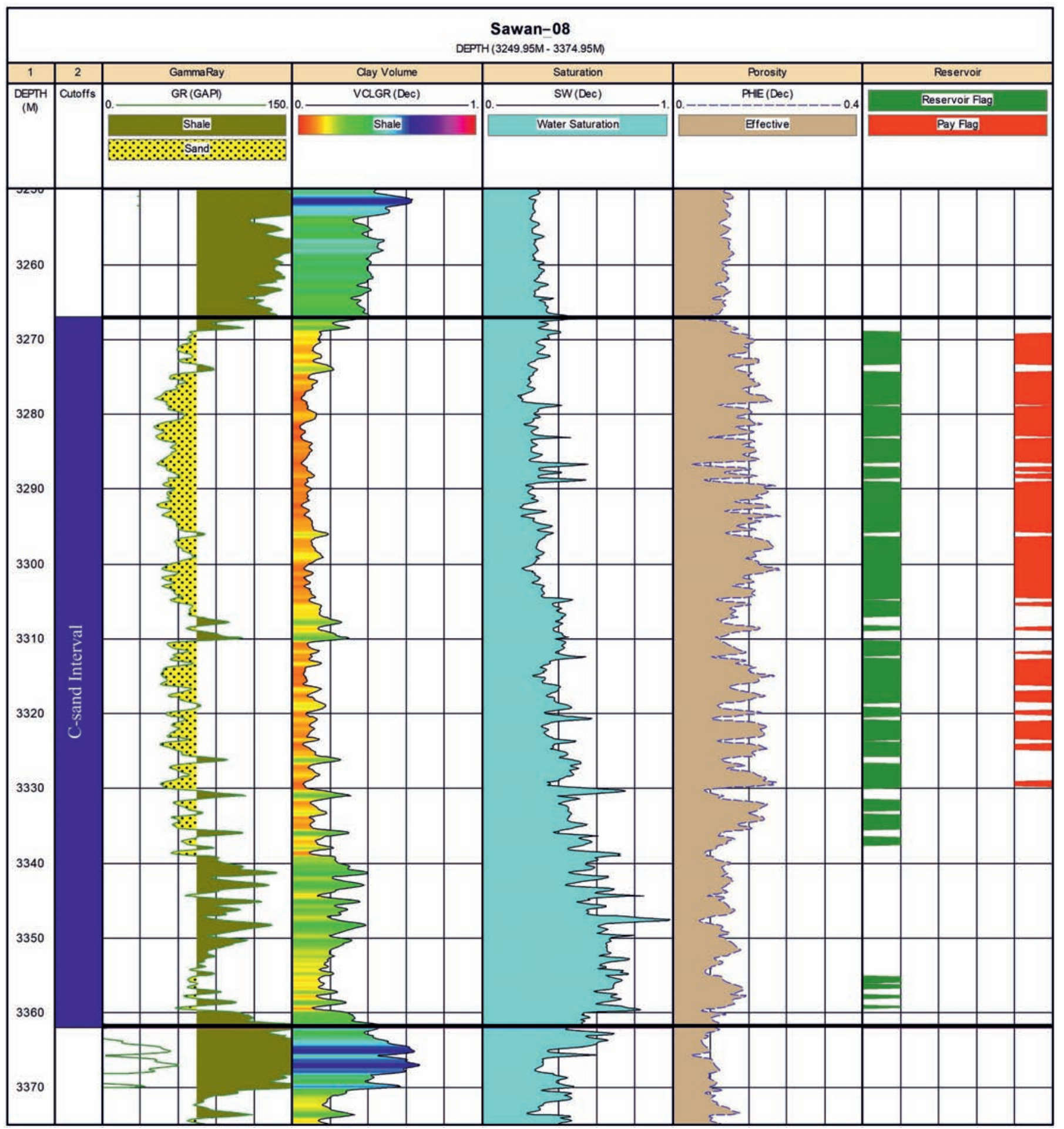

Fig. 4. Log curves and estimated petrophysical parameters within the reservoir C-sand interval of the well Sawan-08

Rys. 4. Profilowania i szacowane parametry petrofizyczne dla piaskowców poziomu złożowego C w otworze Sawan- 08

\section{Rock physics for fluid substitution}

Rock physics models play a vital role in highlighting the variations in reservoir properties with changes in the seismic properties by upscaling the reservoir variables (Avseth et al., 2010). The observed and calculated seismic properties and petrophysical parameters were cross-plotted to quality check the petrophysical results and to observe the extent of variation in reservoir parameters after FRM. In forward models, effective elastic properties are calculated through rock physics models from estimated petrophysical parameters at desired fluid saturations.

The generation of synthetic logs through changing the fluid type and its saturation level at the reservoir is considered as fluid replacement modeling. The bulk modulus of rock is very sensitive to fluid saturation changes, so the modeling of these changes in the seismic properties of the reservoir is possible. 
Table 1. Petrophysical analysis of the Sawan wells used in this study

Tabela 1. Wyniki analizy petrofizycznej dla otworów Sawan-01 i Sawan-08 wykorzystane w niniejszej pracy

\begin{tabular}{|l|c|c|}
\hline \multicolumn{1}{|c|}{ Reservoir properties } & Sawan-01 & Sawan-08 \\
\hline \hline Depth range [m] & $3247-3357$ & $3267-3362$ \\
\hline Gross thickness [m] & 110 & 95 \\
\hline Cumulative sandstone thicknesses [m] & 62 & 61 \\
\hline Average Porosity [\%] & 15.8 & 16 \\
\hline Average Effective Porosity [\%] & 14.6 & 14 \\
\hline Net Sand [m] & 67 & 87 \\
\hline Net Play thickness [m] & 45 & 44 \\
\hline Average water saturation [\%] & 46 & 42 \\
\hline Average volume of shale [\%] & 20 & 16 \\
\hline Water resistivity [ohm/m] & 0.06 & 0.06 \\
\hline
\end{tabular}

To observe the changes in seismic properties $\left(V p, V s\right.$, and $\left.\rho_{\text {eff }}\right)$ caused by fluid replacement, Gassmann's equations (1951) are incorporated for isotropic cases. It provides a relationship between the bulk modulus of a fluid-saturated porous rock $\left(K_{s}\right)$, the bulk modulus of the dry frame $\left(K_{d}\right)$, the bulk modulus of the rock matrix $\left(K_{m}\right)$, the porosity $(\phi)$, and the bulk modulus of the pore fluid $\left(K_{f}\right)$. A typical form of the Gassmann equation is as follows:

$$
K_{s}=K_{d}+\left\{\frac{\left(1-\left(K_{d} / K_{m}\right)\right)}{\left(\frac{\phi}{K_{f}}+\frac{1-\phi}{K_{m}}-\frac{K_{d}}{K_{m}^{2}}\right)}\right\}
$$

where $K_{d}$ is estimated as a function of porosity using the empirical relationship proposed by Murphy et al. (1993), $K_{m}$ is calculated through the Voigt-Reuss-Hill average methods
(Voigt, 1910; Reuss, 1929; Hill, 1952), and $K_{f}$ can be estimated using Wood's equation (Wood, 1941).

Finally, the velocities $V p$ and $V s$ are estimated using the equation:

$$
V_{P}=\sqrt{\frac{K s+(4 / 3) \mu}{\rho_{\text {eff }}}}
$$

and

$$
V_{S}=\sqrt{\frac{\mu}{\rho_{e f f}}}
$$

where

$$
\rho_{\text {eff }}=(1-\phi)_{m}+\phi \rho_{f}
$$

and $\rho_{m}$ and $\rho_{f}$ represent the matrix densities and the fluid densities, respectively. The seismic parameters computed via FRM as a function of pore fluids are further used to derive AVO attribute response in forward modeling.

\section{Seismic and AVO calibrations}

Seismic to well tie is carried out using a synthetic seismogram, and three horizons are identified and marked as Lower Goru, C-sand, and Base (C-sand base). The hydrocarbonbearing $\mathrm{C}$-sand reservoir is then identified on the seismic section and mapped across the arbitrary seismic line (Fig. 5a). The time contour map of $\mathrm{C}$-sand top horizon indicated that the reservoir interval is dipping and prograding towards the northeast and acquires the stratigraphic mechanism of hydrocarbon trapping (Fig. 5b).

Synthetic seismograms are generated for AVO forward modeling and reflection coefficients are calculated as a function of incident angles using the exact Zoeppritz equations (1919).

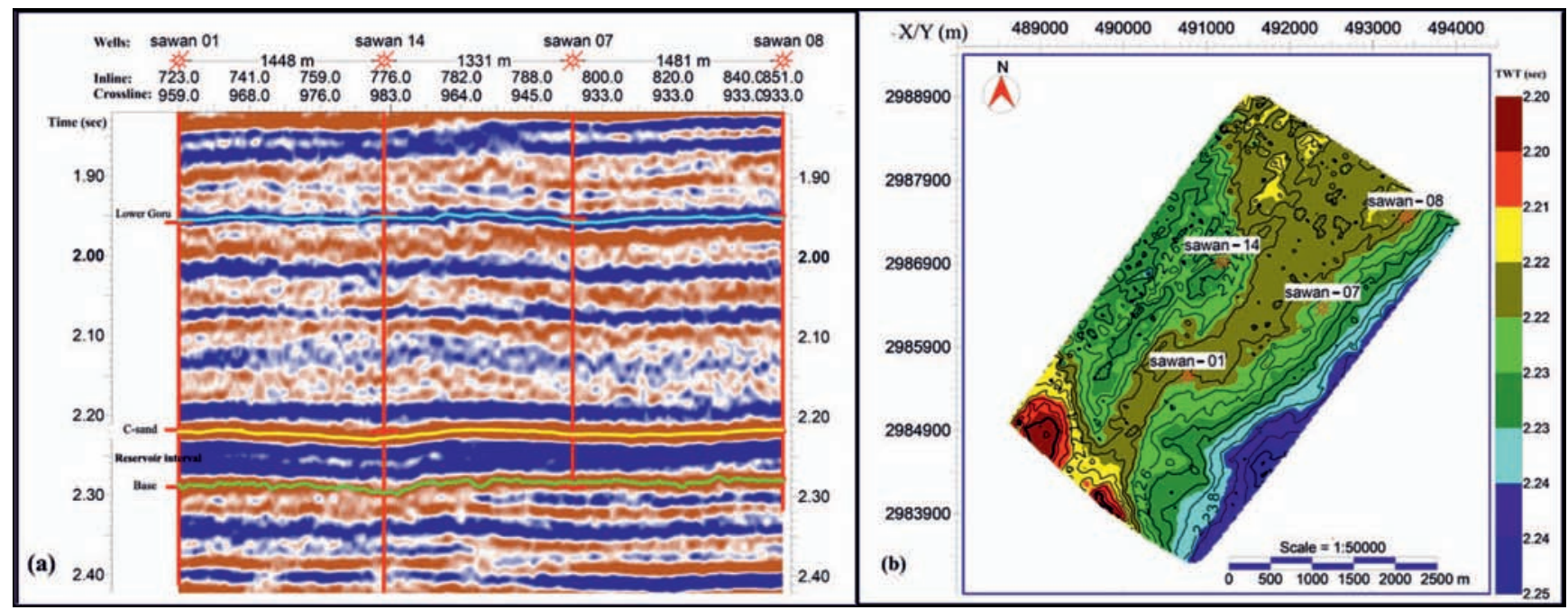

Fig. 5. a) Interpreted seismic section showing the horizons and well locations encountered in the reservoir interval, b) Time contour map of reservoir C-sand top horizon showing the dipping and prograding trend towards the northeast

Rys. 5. a) Zinterpretowany przekrój sejsmiczny przedstawiający horyzonty sejsmiczne i usytuowanie odwiertów w interwale złożowym, b) Mapa czasowa stropu piaskowców poziomu złożowego C uwidaczniająca trend zapadania i progradacji w kierunku NE 
The synthetic common depth points (CDP) gathered at different fluid saturations are generated through the convolution of reflection coefficients (generated from log data) with a constant-phase Ricker wavelet of 25-Hz bandwidth and 2-ms sample interval. The complete work flow adopted for synthetic forward modeling from well log data at the reservoir interface is presented in Figure 6. The synthetic data from well logs and seismic were correlated to analyze the match between them. AVO interpretation was carried out by extracting attributes, including $R_{o}$ and $G_{A}$, by utilizing Shuey's equation (1985). Cross-plotting of $R_{o}$ and $G_{A}$ was used to interpret the AVO class and anomaly. The deviation from the background trend represents the AVO anomaly, which may be related to lithology factors or the existence of hydrocarbons (Smith and Gidlow, 1987).

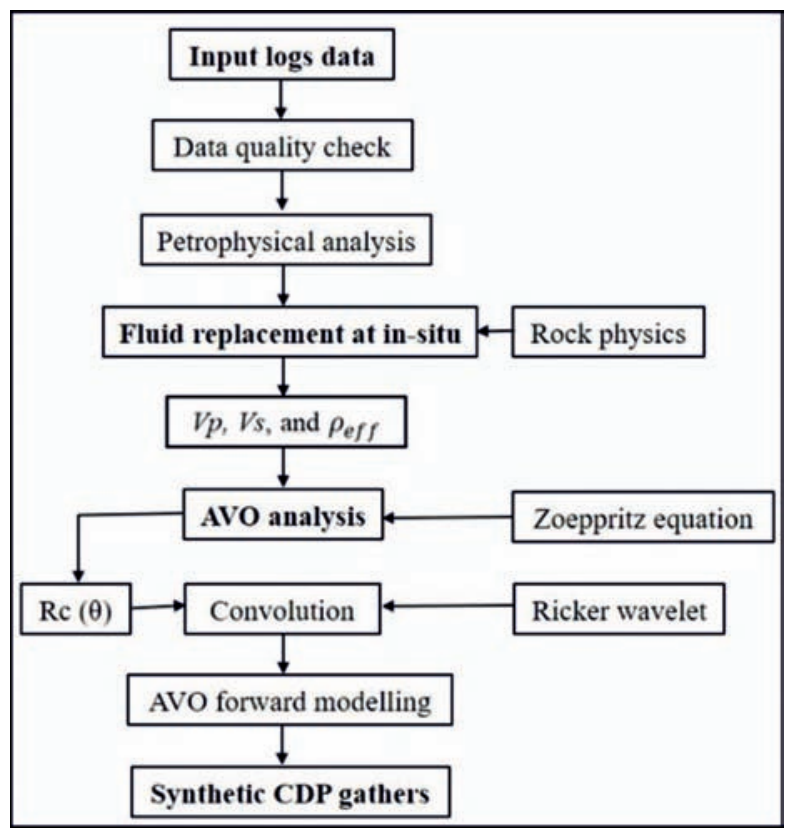

Fig. 6. A complete workflow adopted for AVO synthetic generation Rys. 6. Zastosowana procedura do syntetycznego generowania AVO

\section{Results and discussion}

\section{FRM effect on reservoir elastic parameters}

The initial water saturation levels of Sawan-01 and Sawan-08 wells were $46 \%$ and $42 \%$, respectively. The shale volume $\left(V_{s h}\right)$ calculated from GR logs was used to determine the reservoir sand (shale $<0.4 v / v)$ and shale $(>0.4 v / v)$. The FRM is calculated for pure sandstones to measure the sensitivity at a saturation level of $80 \%$ gas and $20 \%$ water.

The hydrocarbon fluid present in the reservoir strongly influences the seismic parameters. The $V p, V s$, and $R h o(\rho)$ are plotted as a function of fluid concentration in Figure 7. As $S_{w}$ decreases, the saturation of gas increases, resulting in a decrease in $V p$ and $\rho$, but a slight increase in $V s$. We know that shear modulus is independent of the presence of fluid and its type, and that the increase in $V s$ is due to the change in $\rho$ after FRM. The $V p$ curve for both wells showed a drastic decrease along with a decrease in $S_{w}$, from $100 \%$ to $80 \%$, and a gradual increase, from 50\% and 25\% backward, in Sawan-01

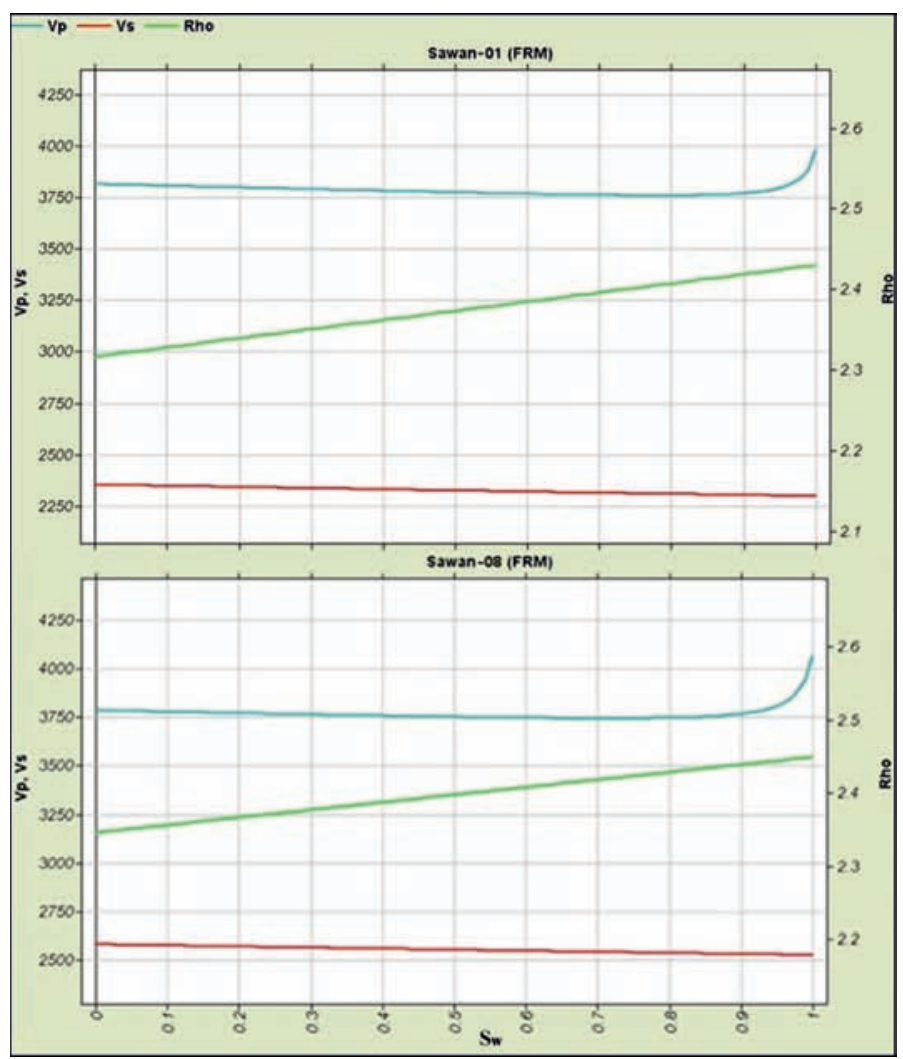

Fig. 7. Saturation effect after FRM on the seismic properties of C-sand reservoir for Sawan-01 (above) and Sawan-08 (below)

Rys. 7. Wpływ nasycenia po FRM na właściwości sejsmiczne piaskowców poziomu złożowego C odpowiednio dla otworów Sawan-01 (powyżej) oraz Sawan-08 (poniżej)

Table 2. Average changes observed in the elastic properties of reservoir C-sand interval due to changes in saturation level

Tabela 2. Uśrednione zmiany obserwowane we właściwościach sprężystych piaskowców poziomu złożowego C z powodu zmiany poziomu nasycenia

\begin{tabular}{|c|c|c|c|c|c|c|c|c|c|}
\hline \multirow{2}{*}{ Wells } & $V p$ & $V p$ & Change & $V s$ & Vs & Change & $\rho$ & $\rho$ & Change \\
\hline & [in situ] & [FRM] & [\%] & [in situ] & [FRM] & [\%] & [in situ] & [FRM] & [\%] \\
\hline Sawan-01 & 3974.2 & 3907.4 & 1.7 & 2298 & 2327 & -1.2 & 2.43 & 2.37 & 2.5 \\
\hline Sawan-08 & 4060.3 & 3968.4 & 2.3 & 2525 & 2558 & -1.3 & 2.45 & 2.39 & 2.4 \\
\hline
\end{tabular}




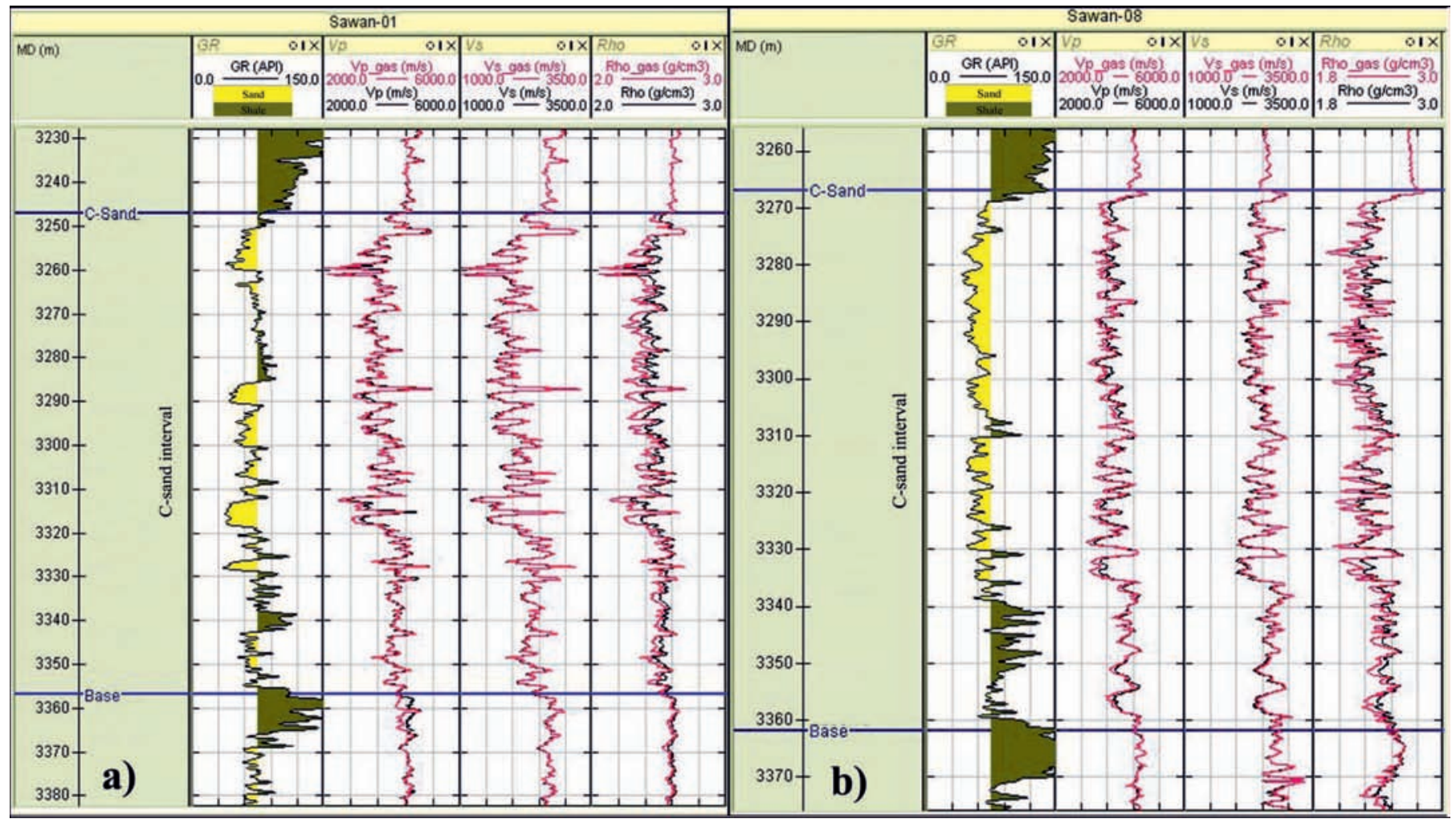

Fig. 8. The logs of reservoir elastic properties $(V p, V s$, and $R h o$ ) from a) Sawan-01 and b) Sawan-08 are shown before (black) and after FRM (red)

Rys. 8. Profile właściwości sprężystych ( $V p, V s$, i Rho) poziomu złożowego w otworze Sawan-01 (a) oraz Sawan-08 (b) odpowiednio przed FRM (czarny) i po FRM (czerwony)

and Sawan-08, respectively. There is a constant decrease in the $\rho$ curve and a slight gradual increase in the $V s$ curve with decreasing $S_{w}$ in both wells. Moreover, the variations in rock properties after FRM are more prominent towards lower values as compared with the in situ condition in both wells. The response can also be observed in measured (in situ) and modeled (FRM) logs of reservoir elastic properties in both wells, Sawan-01 and Sawan-08 (Fig. 8). The average changes in elastic properties in the sands in situ and after FRM for both wells are listed in Table 2.

\section{AVO analysis}

Using the average calculated velocities and densities for shale and the underlying reservoir sand, the AVO response is calculated in situ and for a gas-saturated reservoir in FRM. The exact Zoeppritz equation is used to compute P-wave reflectivity $\left(R_{p p}\right)$ as a function of incident angle $(\theta)$ for background in situ C-sand and for C-sand after FRM (Fig. 9). The overlaying shale's acoustic impedance ( $V p . \rho)$ is higher than that of either sand (Table 3), give rise to the negative value of reflectivity in both wells. The $R_{p p}$ as a function of $\theta$ for C-sand after FRM is lower than in situ $\mathrm{C}$-sand. The AVO has a negative reflection amplitude and gradient at normal incidence, and it progressively shifts towards the lower values at the far offsets. However, there is a small and relatively constant separation between the in situ C-sand and FRM C-sand responses, suggesting similar behavior in near and far angle stacks under isotropic conditions. The normal incidence (intercept) has a low negative value with higher amplitudes in Sawan-01 as compared to Sawan-08 at the far offsets. The hydrocarbon fluid present in the reservoir strongly influences the seismic parameters. $R_{o}$ and $G_{A}$ were calculated and cross-plotted for fifty samples at interfaces in the $\mathrm{R}_{\mathrm{o}}-G_{A}$ plane (Fig. 10). The top interface of in situ C-sand and FRM C-sand has a negative $R_{o}$ and a positive $G_{A}$, and lies in the second quadrant; thus, the gas anomaly indicates that a class IV reservoir is present in the study area. There is a great deal of overlap in the direction of gradient between in situ C-sand and FRM C-sand; however, the cross-plot shows the deviation of FRM C-sand from the background trend. The change in $R_{o}$ and $G_{A}$ in both wells is listed in Table 4.

In the wells Sawan-01 and Sawan-08, the reservoir zone of $\mathrm{C}$-sand interval was selected for FRM and AVO synthetic generation. The CDP gathers at in-situ and under FRM conditions were generated to characterize the effect of fluid saturation on seismic AVO (Figs. 11 and 12). Synthetic gathers at in-situ have shown a good match with the seismic and indicate a decrease in amplitude response with angle in Sawan-01, while showing no change in amplitude with angle in Sawan-08. However, FRM 


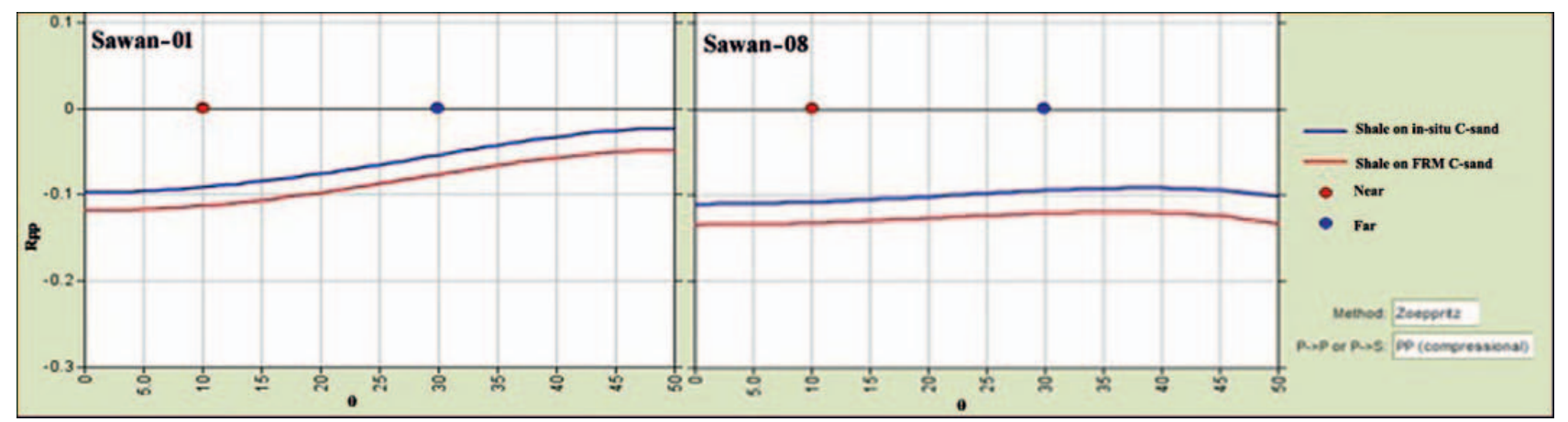

Fig. 9. A half-space model showing the P-wave reflectivity $\left(R_{p p}\right)$ versus the incidence angle $(\theta)$ for C-sand reservoir in Sawan-01 and Sawan-08. The $\theta$ for near offset (red dot) and far offset (blue dot) reflectivity is at 10 and 30 degrees, respectively

Rys. 9. Wykres przedstawiający zależność współczynnika odbicia fali $\mathrm{P}\left(R_{p p}\right)$ od kąta padania $(\theta)$ dla piaskowców poziomu złożowego C w otworach Sawan-01 i Sawan-08. Kąt $\theta$ dla współczynnika odbicia bliskiego (punkt czerwony) i dalekiego (punkt niebieski) offsetu wynosi odpowiednio 10 i 30 stopni

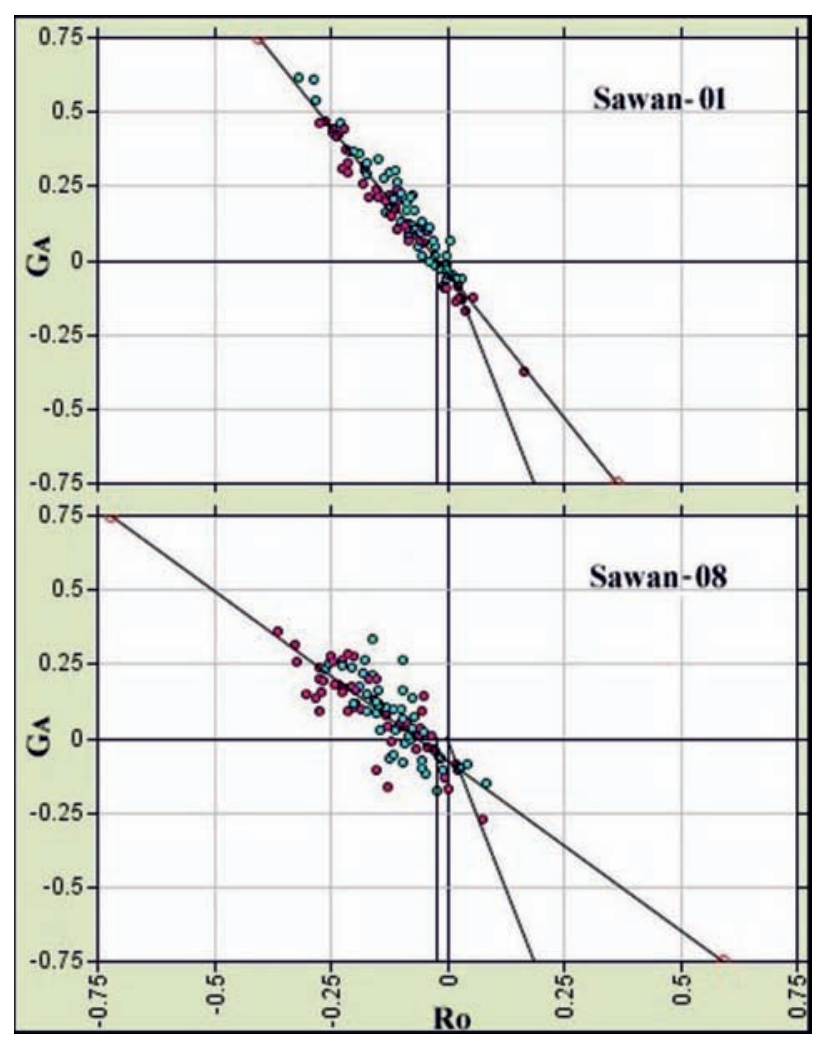

Fig. 10. In situ C-sand (blue dots) and FRM C-sand (red dots) indicating the potential effects of gas saturation on the reflectivity at the reservoir interface in Sawan-01 and Sawan-08

Rys. 10 Piaskowiec C in situ (niebieskie kropki) oraz po FRM (czerwone kropki) wykazujący potencjalny wpływ nasycenia gazem na współczynniki odbicia na granicy poziomu złożowego w otworach Sawan-01 i Sawan-08

synthetic gathers showed an increase in amplitude with angle in both wells, indicating the amplitudes' sensitivity with the replacement of pore fluid saturation. Identifying the sand/shale interface response in the reservoir zone is difficult because of thin shale layering. A possible top sand response is shown by the red line at C-sand marker (Figs. 11 and 12). Here, a class IV AVO response can be seen more prominently as the result
Table 3. Average values of elastic properties in the shale medium within the reservoir interval

Tabela 3. Uśrednione wartości właściwości sprężystych w ośrodku łupkowym w obrębie interwału złożowego

\begin{tabular}{|c|c|c|c|}
\hline Wells & $\boldsymbol{V p}$ & $\boldsymbol{V} \boldsymbol{\rho}$ & $\boldsymbol{\rho}$ \\
\hline \hline Sawan-01 & 4430.2 & 2622.5 & 2.65 \\
\hline Sawan-08 & 4629.4 & 2674.4 & 2.68 \\
\hline
\end{tabular}

Table 4. AVO intercept (Ro) and gradient (GA) attributes to discriminate gas saturation levels

Tabela 4. Atrybuty AVO Intercept (Ro) i AVO Gradient $\left(\mathrm{G}_{\mathrm{A}}\right)$ rozróżniające poziom nasycenia gazem

\begin{tabular}{|c|c|c|c|c|}
\cline { 2 - 5 } \multicolumn{1}{c|}{} & \multicolumn{2}{c|}{ in situ C-sand } & \multicolumn{2}{c|}{ FRM C-sand } \\
\hline Wells & Ro & $\boldsymbol{G}_{\boldsymbol{A}}$ & $\boldsymbol{R o}$ & $\boldsymbol{G}_{\boldsymbol{A}}$ \\
\hline \hline Sawan-01 & -0.085 & 0.151 & -0.116 & 0.177 \\
\hline Sawan-08 & -0.108 & 0.063 & -0.135 & 0.064 \\
\hline
\end{tabular}

of harder lithology (shale) overlying the gas-bearing sand body. It can be observed that FRM synthetic at $\mathrm{C}$-sand interface show prominent phase reversal from trough to peak on the far offset angle gathers in Sawan-01 compared to Sawan-08.

\section{Conclusion}

Fluid replacement based on the Gassmann model is a tool used to map variation in reservoir properties at different saturation levels. In the present study, AVO behavior and seismic response of reservoir elastic parameters was analyzed through the FRM of a reservoir C-Sand interval in the study region. A significant change was found in the elastic properties of the reservoir with a change in fluid saturation level.

The identified variations were demonstrated in AVO synthetic gathers generated from $\log$ data and seismic around the 


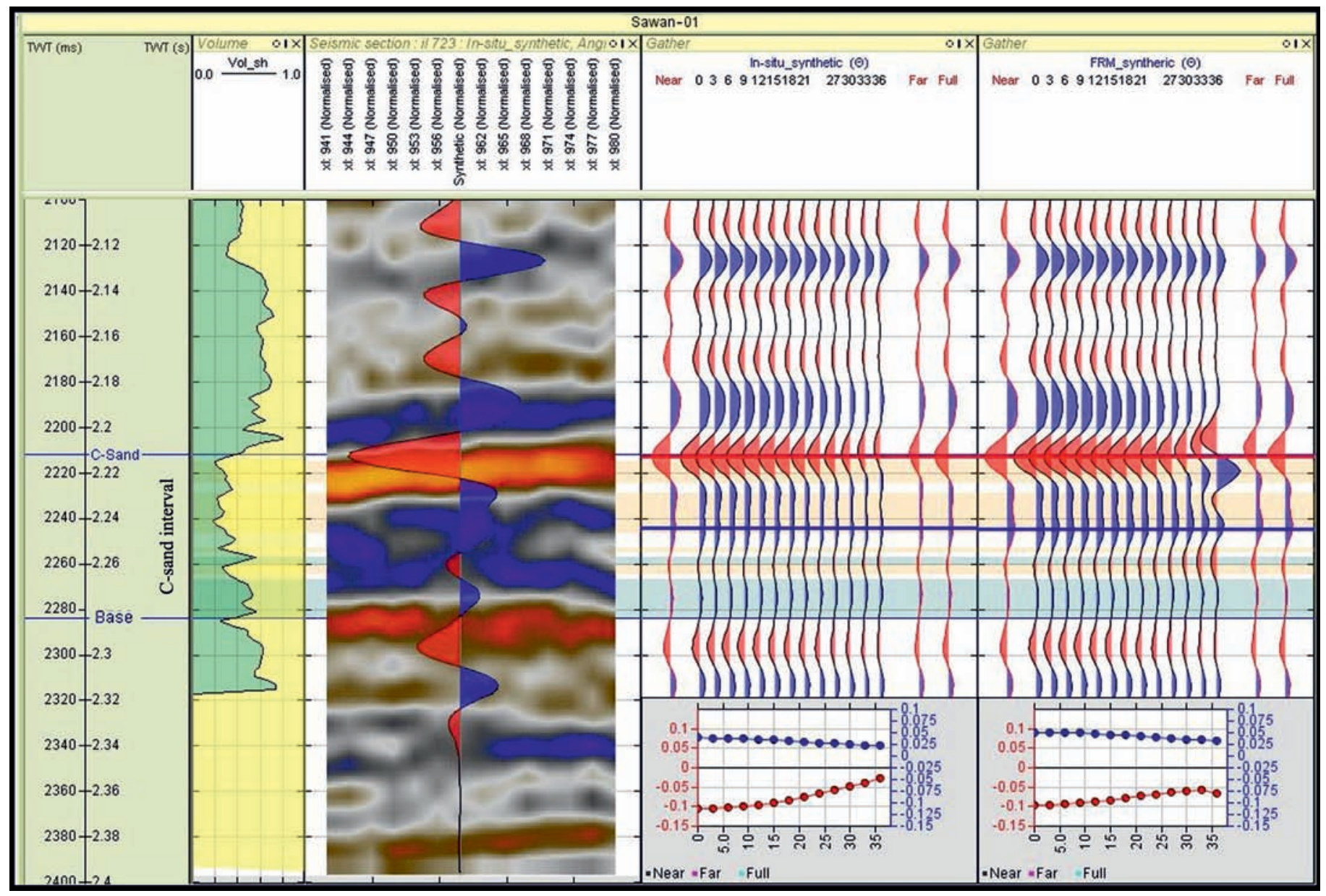

Fig. 11. AVO synthetic gathers in the reservoir with changing fluid saturation around Sawan-01. The tracks from left to right represent $V s h, 3 \mathrm{D}$ post-stack seismic section displaying the seismic trace along the well path, in situ synthetic, and FRM synthetic gathers, respectively. At the bottom of the synthetic gathers are the amplitude reflectivities

Rys. 11. Syntetyczne kolekcje AVO w złożu o zmieniającym się nasyceniu wokół lokalizacji otworu Sawan-01. Kolumny od lewej do prawej reprezentują: Vsh, fragment sekcji sejsmicznej 3D typu post-stack przedstawiający odpowiednio trasę sejsmiczną wzdłuż trajektorii otworu, zestaw tras syntetycznych in situ oraz zestaw tras syntetycznych po FRM. Poniżej zestawów tras syntetycznych zamieszczono wykresy odpowiedzi amplitudowej

wells. The effect of FRM on AVO amplitude is more prominently seen at far angles due to the gas saturation effect. The $R_{o}$ and $G_{A}$ values indicated that a class IV gas anomaly is present in the reservoir zone and its signatures are enhanced due to an increase in gas saturation in FRM. The reservoir parameters and AVO responses are well-captured in the analysis with variable fluid saturation levels for effective reservoir characterization. The technique of FRM is helpful in the robust identification of reservoir lithology and fluid type by analyzing the AVO behavior of elastic parameters.

Acknowledgments. The authors would like to give special recognition to the Directorate General of Petroleum Concessions (DGPC), Pakistan, for the release of 3D seismic and well-log data in order to accomplish the research work. We also gratefully acknowledge the Department of Earth Sciences at Quaid-i-Azam University for providing basic research requirements for research students and access to the relevant software.

\section{References}

Afzal J., Kuffner T., Rahman A., Ibrahim M., 2009. Seismic and well$\log$ based sequence stratigraphy of the early Cretaceous, Lower Goru "C" sand of the Sawan gas field, middle Indus Platform, Pakistan. Proceedings, Society of Petroleum Engineers (SPE)/ Pakistan Association of Petroleum Geoscientists (PAPG) Annual Technical Conference, Islamabad, Pakistan.

Aki K., Richards P.G., 1980. Quantitative seismology: theory and methods. W.H. Freeman, San Francisco: 558-932.

Avseth P., Mukerji T., Mavko, G., 2010. Quantitative seismic interpretation: Applying rock physics tools to reduce interpretation risk. Cambridge University Press.

Batzle M.L., Han D.H., Hofmann R., 2001. Optimal hydrocarbon indicators. [In:] Annual International Meeting, SEG expanded abstracts. San Antonio, Texas, 1697-1700.

Berger A., Gier S., Krois P., 2009. Porosity-preserving chlorite cements in shallow-marine volcaniclastic sandstones: evidence from cretaceous sandstones of the Sawan gas field, Pakistan. Am. Assoc. Petrol. Geol. Bull., 93(5): 595-615.

Castagna J.P., Smith S.W., 1994. Comparison of AVO indicators: a modeling study. Geophysics, 59: 1849-1855. 


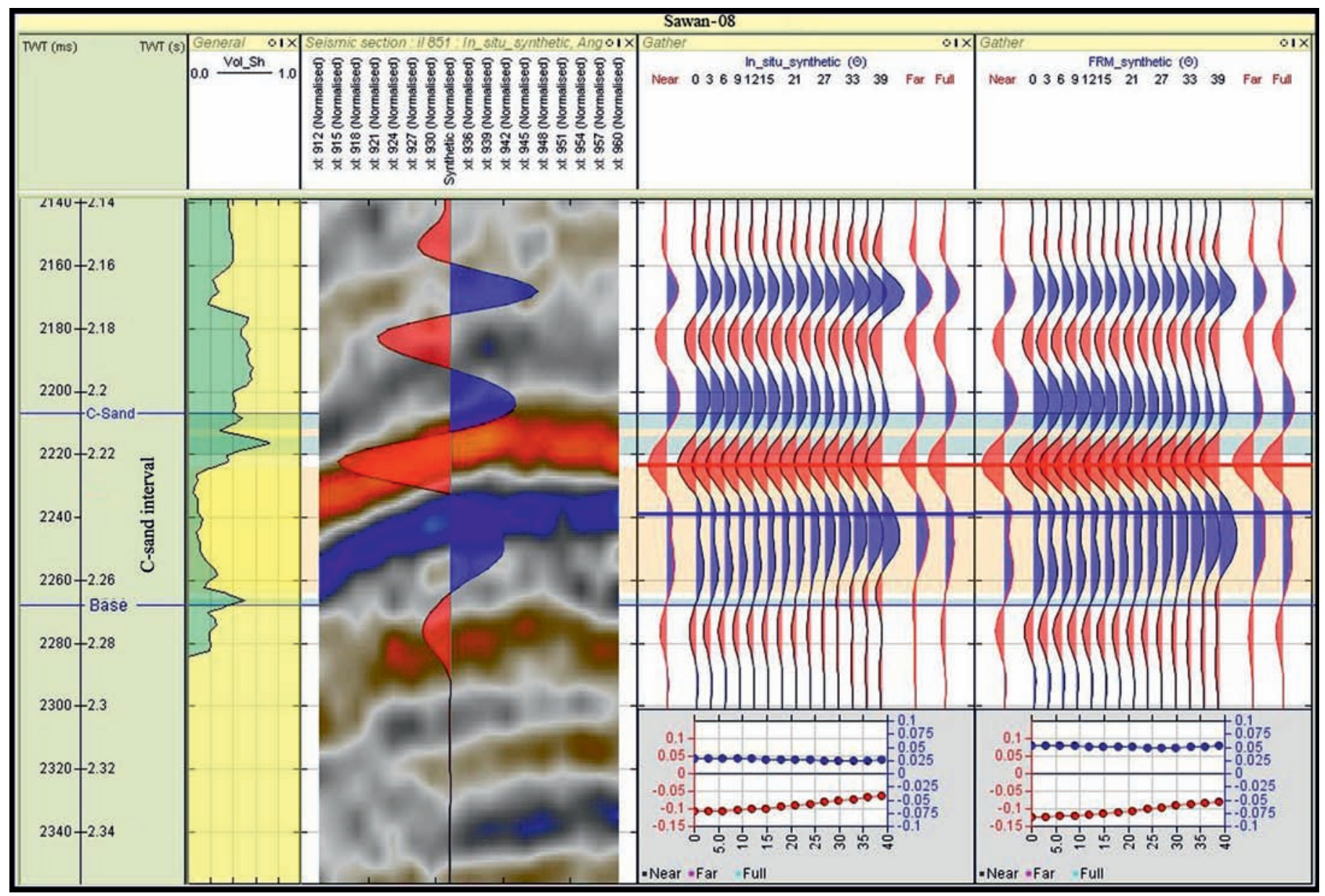

Fig. 12. AVO synthetic gathers in the reservoir with changing fluid saturation around Sawan-08. The tracks from left to right represent $V s h, 3 \mathrm{D}$ post-stack seismic section displaying the seismic trace along the well path, in situ synthetic, and FRM synthetic gathers, respectively. At the bottom of the synthetic gathers are the amplitude reflectivities

Rys. 12. Syntetyczne kolekcje AVO w złożu o zmieniającym się nasyceniu wokół lokalizacji otworu Sawan-08. Kolumny od lewej do prawej reprezentują: Vsh, fragment sekcji sejsmicznej 3D typu post-stack przedstawiający odpowiednio trasę sejsmiczną wzdłuż trajektorii otworu, zestaw tras syntetycznych in situ oraz zestaw tras syntetycznych po FRM. Poniżej zestawów tras syntetycznych zamieszczono wykresy odpowiedzi amplitudowej

Castagna J.P., Swan H.W., 1997. Principles of AVO crossplotting. The Leading Edge, 16: 337-342.

Castagna J.R., Swan H.W., Foster D.J., 1998. Framework for AVO gradient and intercept interpretation. Geophysics, 63: 948-956.

Fatti, J.L., Vail P.J., Smith G.C., Strauss P.J., Levitt P.R., 1994 Detection of gas in sandstone reservoirs using AVO analysis: a 3-D seismic case history using the geostack technique. Geophysics, 59:1362-1376.

Gassmann F., 1951. Elastic waves through a packing of spheres, Geophysics, 16: 673-685. DOI: 10.1190/1.1437718.

Grana D., Pirrone M., Mukerji M., 2012. Quantitative log interpretation and uncertainty propagation of petrophysical properties and facies classification from rock-physics modeling and formation evaluation analysis. Geophysics, 77: 45-63. DOI: 10.1190/ geo2011-0272.1.

Gray D., Goodway W., Chen T., 1999. Bridging the gap: using AVO to detect changes in fundamental elastic constants. Annual international meeting, SEG expanded abstracts, 852-855. DOI: 10.1190/1.1821163.

Hill R., 1952. The elastic behavior of a crystalline aggregate. Proceedings of the Physical Society, Section A, 65(5):349-354.

Kazmi A.H., Jan M.Q., 1997. Geology and Tectonics of Pakistan. Graphic Publishers, Karachi, Pakistan.
Mavko G., Mukerji T., Dvorkin J., 2009. The Rock Physics Handbook; Tools for Seismic Analysis of Porous Media. Cambridge University Press, UK.

Murphy W., Reischer A., Hsu K., 1993. Modulus decomposition of compressional and shear velocities in sand bodies. Geophysics, 58:227-239. DOI: 10.1190/1.1443408.

Ostrander W.J., 1984. Plane-wave reflection coefficients for gas sands at non normal angles of incidence. Geophysics, 49 (10): 1637-1648. DOI: 10.1190/1.1441571.

Quadri V.N., Shuaib M., 1986. Hydrocarbon prospects of Southern Indus Basin. AAPG Bull., 70: 730-747.

Reuss A., 1929. Berechnung der Fliessgrenze von Mischkristallen auf Grund der Plastizitätsbedingung für Einkristalle. ZAMMJournal of Applied Mathematics and Mechanics/Zeitschrift für Angewandte Mathematik und Mechanik, 9: 49-58.

Rizwan M., Akhter G., Mustafa A., Bin Nisar U., Ashfaq K., 2018. Amplitude versus offset (AVO) modelling and analysis for quantitative interpretation of porosity and saturation: A case study for Sawan gas field, middle Indus basin, Pakistan. Geofisica Internacional, 57(2): 151-160.

Rutherford S., Williams R., 1989. Amplitude-versus-offset variations in gas sands. Geophysics, 54: 680-688. DOI: 10.1190/1.1442696.

Seeber L., Quittmeyer R.C., Armbruster J.G., 1980. Seismotectonics 
of Pakistan: a review of results from network data and implications for the Central Himalayas. Geol. Bull. Univ. Peshawar, 13: 151-68.

Shuey R.T., 1985. A simplification of the Zoeppritz equations. Geophysics, 50: 609-614. DOI: 10.1190/1.1441936.

Singleton S., Kierstead R., 2009. Calibration of prestack simultaneous impedance inversion using rock physics. Society of Exploration Geophysics, Expanded Abstracts, 1815-1819. DOI: 10.1190/1.3535435.

Smith G.C., Gidlow P.M., 1987. Weighted stacking for rock property estimation and detection of gas. Geophysical Prospecting, 35: 993-1014. DOI: 10.1111/j.1365-2478.1987.tb00856.x.

Smith T.M., Sondergeld C.H., Rai C.S., 2003. Gassmann fluid substitutions: A tutorial. Geophysics, 68(2): 430-440. DOI: 10.1190/1.1567211.

Voigt W., 1910. Lehrbuch der Kristallphysik. Teubner Verlagsgesellschaft, Leipzig

Wood A.B., 1941. A textbook of sound. G. Bell and sons, London.

Yuping, S., Yunguang, T., Tianqi, W., Guangpo, C., Jian, L., 2010. AVO attributes interpretation and identification of lithological traps by prestack elastic parameters inversion - A case study in K Block, South Turgay Basin. SEG Technical Program Expanded Abstracts 2010. DOI: 10.1190/1.3513794.
Zaigham N.A., Mallick K.A., 2000. Bela ophiolite zone of southern Pakistan: Tectonic setting and associated mineral deposits: GSA Bulletin, 112(3): 478-489.

Zoeppritz K., 1919. On the Reflection and Propagation of Seismic Waves. Göttinger Nachrichten, I: 66-84.

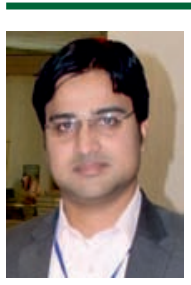

Muhammad Rizwan MUGHAL Ph.D.

Ph. D. Scholar at the Department of Earth Sciences, Quaid-i-Azam University (QAU)

Islamabad, Pakistan

Research Associate at the Department of Meteorology COMSATS University Islamabad (CUI), Pakistan E-mail:mmrizwan@student.qau.edu.pk

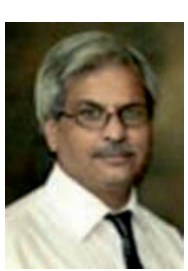

Gulraiz AKHTER

Professor \& Chairman at the Department of Earth Sciences,

Quaid-i-Azam University (QAU)

Islamabad, Pakistan

E-mail:agulraiz@qau.edu.pk

\section{OFERTA BADAWCZA ZAKKADU INŻYNIERII NAFTOWEJ}

analiza przyczyn oraz badania stopnia uszkodzenia skał zbiornikowych w strefie przyotworowej; ocena gtębokości infiltracij fazy ciektej do skat zbiornikowych;

ocena wptywu roztworów soli i cieczy wiertniczych na skały ilaste strefy przyotworowej

pomiary parametrów reologicznych cieczy i niektórych ciat statych w zakresie temperatur od -40 do $200^{\circ} \mathrm{C}$ oraz ciśnień do 150 bar;

badania oraz dobór cieczy roboczych i solanek do prac związanych z opróbowaniem i rekonstrukcją odwiertów: ocena stateczności ścian otworów wiertniczych;

określanie zdolności produkcyinej odwiertów;

symulacja eksploatacji kawernowych podziemnych magazynów gazu w wysadach solnych, z uwzględnieniem konwergencji komór:

zastosowanie technologii mikrobiologicznych do stymulacji odwiertów oraz usuwania osadów parafinowych w odwiertach i instalacjach napowierzchniowych;

projektowanie zabiegów mikrobiologicznej intensyfikacji wydobycia ropy (MEOR);

projektowanie zabiegów odcinania doptywu wód ztożowych do odwiertów;

określanie nieredukowalnego nasycenia próbek skaty wodą ztożową;

testy zawadniania z użyciem wody, solanki lub $\mathrm{CO}_{2}$;

fotograficzne dokumentowanie rdzeni wiertniczych;

określanie właściwości mechanicznych oraz sejsmoakustycznych skat w próbach okruchowych;

analiza zjawisk migracij i ekshalacii gazu ziemnego oraz występowania ciśnień w przestrzeniach międzyrurowych; modelowanie obiektów złożowych i opracowywanie specjalistycznego oprogramowania z zakresu inżynierii naftowej.

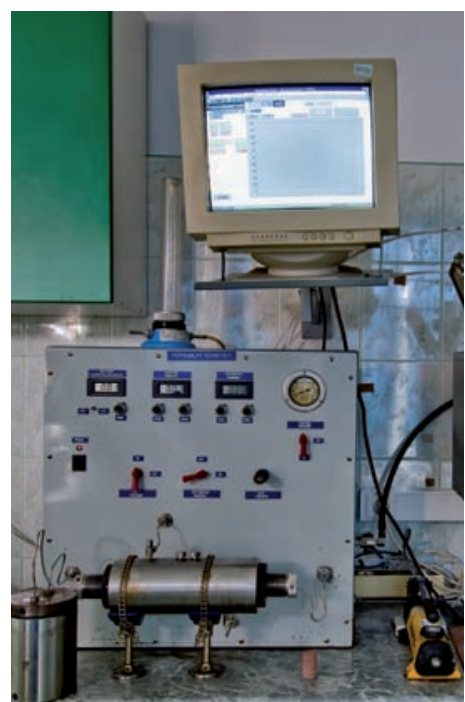

INSTYTUT NAFTY I GAZU

- Państwowy Instytut Badawczy 